\title{
Meripilus giganteus ethanolic extract exhibits pro-apoptotic and anti-proliferative effects in leukemic cell lines
}

\author{
Monia Lenzi ${ }^{1 \dagger}$, Veronica Cocchi ${ }^{1 \dagger}$, Aleksandra Novaković ${ }^{2}$ Maja Karaman ${ }^{3}$, Marijana Sakač², Anamarija Mandić², \\ Milica Pojić ${ }^{2}$, Maria Cristina Barbalace ${ }^{4}$, Cristina Angeloni ${ }^{5}$, Patrizia Hrelia ${ }^{1}$, Marco Malaguti ${ }^{4{ }^{* \dagger}}$ (D) and Silvana Hrelia ${ }^{4 \dagger}$
}

\begin{abstract}
Background: The interest towards botanicals and plant extracts has strongly risen due to their numerous biological effects and ability to counteract chronic diseases development. Among these effects, chemoprevention which represents the possibility to counteract the cancerogenetic process is one of the most studied. The extracts of mushroom Meripilus giganteus (MG) (Phylum of Basidiomycota) showed to exert antimicrobic, antioxidant and antiproliferative effects. Therefore, since its effect in leukemic cell lines has not been previously evaluated, we studied its potential chemopreventive effect in Jurkat and HL-60 cell lines.

Methods: MG ethanolic extract was characterized for its antioxidant activity and scavenging effect against different radical species. Moreover, its phenolic profile was evaluated by HPLC-MS-MS analyses. Flow cytometry (FCM) analyses of Jurkat and $\mathrm{HL}-60$ cells treated with MG extract (0-750 $\mu \mathrm{g} / \mathrm{mL})$ for 24-72 h- allowed to evaluate its cytotoxicity, proapoptotic and anti-proliferative effect. To better characterize MG pro-apoptotic mechanism ROS intracellular level and the gene expression level of FAS, BAX and BCL2 were also evaluated. Moreover, to assess MG extract selectivity towards cancer cells, its cytotoxicity was also evaluated in human peripheral blood lymphocytes (PBL).
\end{abstract}

Results: MG extract induced apoptosis in Jurkat and HL-60 cells in a dose- and time- dependent manner by increasing BAX/BCL2 ratio, reducing ROS intracellular level and inducing FAS gene expression level. In fact, reduced ROS level is known to be related to the activation of apoptosis in leukemic cells by the involvement of death receptors. MG extract also induced cell-cycle arrest in $\mathrm{HL}-60$ cells. Moreover, $\mathrm{IC}_{50}$ at $24 \mathrm{~h}$ treatment resulted 2 times higher in PBL than in leukemic cell lines.

Conclusions: Our data suggest that MG extract might be considered a promising and partially selective chemopreventive agent since it is able to modulate different mechanisms in transformed cells at concentrations lower than in non-transformed ones.

Keywords: Meripilus giganteus, Cytotoxicity, Apoptosis, Chemoprevention, Flow-cytometry, Leukemic cell lines

\section{Background}

Mushrooms have been used for centuries as food all over the world, due to their unique taste and flavour [1]. Archaeological knowledge shows that humans have been using mushrooms since the Palaeolithic [2] and traditional uses in the treatment of infectious diseases have

\footnotetext{
* Correspondence: marco.malaguti@unibo.it

${ }^{\dagger}$ Monia Lenzi, Veronica Cocchi, Marco Malaguti and Silvana Hrelia contributed equally to this work.

${ }^{4}$ Department for Life Quality Studies, University of Bologna, Corso d'Augusto 237, 47921 Rimini, Italy

Full list of author information is available at the end of the article
}

been previously described especially in Asian countries [3]. Over the last few years the interest in therapeutic potential of different species of lignicolous mushrooms has increased, justified by the traditional use of these organisms in the folk medicine of many countries $[4,5]$.

Meripilus giganteus (MG) is a ligniculous saprobiontic or parasite mushroom, which fructifies from summer to autumn at the base of broad-leaved trees, on stumps and roots, especially on beech wood. It derives its name

(c) The Author(s). 2018 Open Access This article is distributed under the terms of the Creative Commons Attribution 4.0 International License (http://creativecommons.org/licenses/by/4.0/), which permits unrestricted use, distribution, and reproduction in any medium, provided you give appropriate credit to the original author(s) and the source, provide a link to the Creative Commons license, and indicate if changes were made. The Creative Commons Public Domain Dedication waiver (http://creativecommons.org/publicdomain/zero/1.0/) applies to the data made available in this article, unless otherwise stated. 
from the remarkable dimensions that it is able to reach: up to a meter in diameter, protruding from the guest trunk for more than $30 \mathrm{~cm}$, with a weight up to $10 \mathrm{~kg}$. The upper portion is zoned, furrowed radially and concentrically by streaks of light brown to dark colour, wrinkled and covered with numerous scales. The tissue is initially soft and tenacious, and then becomes fibrous, leathery and whitish, blackening on contact or rubbing.

Although the young tops are edible after cooking, the completely grown mushroom is considered not edible due to its hard and tough consistency. For these reasons it is considered a species of little value in the culinary field.

Recently MG has drawn the attention of several scientists on its pharmacological properties such as antioxidant, antimicrobial, and anti-proliferative activities.

Karaman et al. [5, 6] investigated the antioxidant and antimicrobial activity of numerous lignicolous mushroom extracts. They demonstrated that MG extract exerts both DPPH radical (DPPH') and hydroxyl radical $\left(\mathrm{OH}^{-}\right)$scavenging activity. Moreover, they demonstrated that the antioxidant activity of lignicolous mushroom extracts directly correlate with their phenolic content, that in MG are mainly represented by gallic and protocatechuic acids.

More recently, Maity et al. [7] isolated from the fruiting body of MG a polysaccharide (MGPS), which seems to possess an antioxidant capacity. In detail, it has been shown that increasing concentrations of MGPS are well correlated with the ability to scavenge $\mathrm{OH}^{*}$ and superoxide anion radical $\left(\mathrm{O}_{2}{ }^{--}\right)$. In order to have a more complete understanding of MGPS antioxidant mechanisms, the researchers also investigated its potential as a chelating agent of ferrous ions $\left(\mathrm{Fe}^{2+}\right)$. Also in this case the ability of MGPS to chelate $\mathrm{Fe}^{2+}$ ions was demonstrated [7].

The results obtained from this study seem to confirm what was previously demonstrated by Rai et al. [8], who investigated the antioxidant properties of different MG extracts, finding a similar antiradical action against $\mathrm{OH}^{\circ}$ and $\mathrm{O}_{2}{ }^{*-}$.

Researchers investigated the antimicrobial potential of several fungal species, including MG, against five species of gram-positive bacteria, and four of gram-negative bacteria. The methanolic extracts of MG were shown to have a narrow spectrum of action against gram-negative bacteria, while strongly inhibit the growth of gram-positive species [6]. These data implement results previously obtained by Rai and co-workers [9], who described a moderate antibacterial action of MG against $E$. coli and $P$. aeruginosa.

Many substances with anti-proliferative effect have been isolated from fungi. Tomasi. et al. [10] analysed the effects of numerous methanolic mushroom extracts and demonstrated that MG exerts antiproliferative activity on 3LL murine lung cancer cell line. Previously Narbe et al. [11] isolated ergosterol peroxide from MG extract, which is known for its antiproliferative properties on both solid and liquid cancer models [12, 13].

\section{Aim of the study}

Considering the numerous biological and pharmacological properties of MG extracts, it is possible to hypothesize its application as a chemopreventive agent in leukaemia. Therefore, the aim of this study was to evaluate the antitumor potential of MG ethanolic extract, fully characterized in its phenolic profile and antioxidant properties, in two different leukaemic cell lines. More specifically, its pro-apoptotic and anti-proliferative effects were analysed in human lymphoblastic leukaemia cells (Jurkat cells) and in human promyelocytic leukaemia cells (HL-60 cells). Moreover, expression level of genes involved in apoptotic pathways was evaluated. In addition to evaluating its selectivity towards cancer cells, its cytotoxic effect on non-transformed human peripheral blood lymphocytes (PBL) was also tested.

\section{Methods \\ Materials}

Sodium carbonate, Aluminium trichloride, Sodium acetate, Quercetin, Formic acid, FRAP reagent, Sodium nitroprusside (SNP), Griess reagent, TBA-reagent, Nitro Blue Tetrazolium (NBT), Ethylenediaminetetraacetic acid (EDTA), Ascorbic acid (AA), Gallic acid (GA), DPPH solution, Thiobarbituric acid (TBA), Trichloroacetic acid (TCA), Dimethyl sulfoxide (DMSO), Fetal Bovine Serum (FBS), Formaldehyde, Hanks' balanced salt solution (HBSS), Histopaque-1077, Hoechst 33342, L-Glutamine (L-GLU), Penicillin-Streptomicin (PS), Phitohemagglutinin (PHA), Phosphate buffered saline (PBS), Primers (BAX, BCL2, FAS, GADPH, 18S rRNA), Roswell Park Memorial Institute (RPMI)1640 medium, Triton X-100, 2'-7'-dichlorodihydrofluorescin diacetate (DCFH-DA) were obtained from Sigma Co. (St. Louis, MO). Folin-Ciocalteu reagent (FC) was obtained from Merck (Darmstadt, Germany). Methanol (MeOH), Ethanol $(\mathrm{EtOH})$ were purchased from Zorka (Šabac, Serbia). Guava Cell Cycle Reagent, Guava Nexin Reagent, Guava ViaCount Reagent (all from Merck, Darmstadt, Germany). RNeasy Mini Kit (from QIAGEN GmbH, Hilden, Germany), SsoAdvanced Universal SYBR Green Supermix, iScript cDNA Synthesis Kit (both from BIO-RAD, Hercules, CA, USA).

\section{Meripilus giganteus extract preparation}

The extract was provided by the Institute of Food Technology (FINS) (Novi Sad, Republic of Serbia) as a part of the collaborative activities included in the Horizon 2020 project, FOODSTARS. 
Mushrooms were collected in 2012 in the Sikole area (Serbia), fungal material was identified by Professor Maja Karaman (University of Novi Sad), expert in mycology. A voucher specimen of the fungal material has been deposited at "Buns herbarium" (Department of Biology and Ecology, University of Novi Sad, Serbia) with voucher number: 12-00697. After the exact determination of specie, mushrooms were stored at $-20{ }^{\circ} \mathrm{C}$, freeze dried (Martin Christ $\mathrm{GmbH}$, Germany) and ground to a fine powder. The extraction was obtained by macerating the powder (1 g) with $10 \mathrm{~mL}$ of $80 \%$ ethanol (EtOH) for $24 \mathrm{~h}$ in a shaker at room temperature $\left(25^{\circ} \mathrm{C}\right)$. The extract was filtered through Whatman No. 4 filter paper and, subsequently, the solvent was evaporated to dryness in a Rotavapor at $40{ }^{\circ} \mathrm{C}$ (Büchi, Switzerland) and stored. For further analysis the dried extract was dissolved in ethanol to obtain $5 \%(w / w)$ solution.

\section{Total phenolic content}

Total phenolic content (TP) was determined in the ethanolic extract according to the method by Singleton et al. [14] and modified by Novaković et al. [15]. Briefly, $125 \mu \mathrm{L}$ of Folin-Ciocalteu $(0.1 \mathrm{M})$ reagent were added to $25 \mu \mathrm{L}$ of the extract. After 10 min incubation, $100 \mu \mathrm{L}$ of $7.5 \%$ sodium carbonate was added and the reaction mixture was incubated for $2 \mathrm{~h}$. Absorbance was read at $690 \mathrm{~nm}$ in a plate reader (Multiskan Ascent, Thermo Electron Corporation). A standard curve was constructed using gallic acid in the range of 0 to $1000 \mu \mathrm{mol} / \mathrm{L}$. Total phenolic content was expressed as mg gallic acid equivalents (GAE)/g of extract on dry weight basis.

\section{Total flavonoid content}

The total flavonoid (TF) content of the ethanolic extract was determined by Chang et al. [16] modified for the measurements in a 96-well plate reader [15]. Briefly, $90 \mu \mathrm{L}$ of methanol, $6 \mu \mathrm{L}$ of aluminium trichloride $(0.75 \mathrm{M}), 6 \mu \mathrm{L}$ of sodium acetate $(1 \mathrm{M})$ and $170 \mu \mathrm{L}$ of distilled water were added to $30 \mu \mathrm{L}$ of the extract. After $30 \mathrm{~min}$ incubation absorbance was measured at $414 \mathrm{~nm}$. A standard curve was constructed using quercetin in the range of $1.25-100 \mu \mathrm{g} / \mathrm{mL}$. Results were expressed as $\mathrm{mg}$ quercetin equivalents $(\mathrm{QE}) / \mathrm{g}$ of extract dry weight.

\section{HPLC-MS/MS determination of the phenolic compounds}

Phenolic compounds were determined in the ethanolic extract according to the method of Orčić et al. [17], using an Agilent 1200 series liquid chromatograph equipped with a Zorbax Eclipse XDB-C18 RR $4.6 \mathrm{~mm} \times$ $50 \mathrm{~mm} \times 1.8 \mathrm{~mm}$ column (Agilent Technologies) at $40^{\circ}$ C. The separated compounds were detected by an Agilent series 6410A triple-quadrupole mass spectrometer with electrospray ionization (ESI). MassHunter ver.
B.03.01. Software (Agilent Technologies) was used for instrument control and data analysis. The mobile phase consisted of $0.05 \%$ formic acid (A) and methanol (B) with a flow rate of $1 \mathrm{~mL} / \mathrm{min}$. The following gradient elution was used: at $0 \mathrm{~min}, 30 \% \mathrm{~B}$, at $6.00 \mathrm{~min}$ reaching $70 \% \mathrm{~B}$, then at $9.00 \mathrm{~min} 100 \% \mathrm{~B}$, holding until $12.00 \mathrm{~min}$, followed by equilibration time of $3 \mathrm{~min}$ to the starting mixture of $30 \%$ B. Samples were injected automatically, the injection volume for all samples was $5 \mu \mathrm{L}$. ESI parameters were: drying gas $\left(\mathrm{N}_{2}\right)$ at $350{ }^{\circ} \mathrm{C}$, flow of $9 \mathrm{~L} / \mathrm{min}$, nebulizer gas pressure of $40 \mathrm{psi}$, capillary voltage of $4 \mathrm{kV}$ with negative polarity. All compounds were quantified in dynamic MRM mode (multiple reaction monitoring mode). The stock solution was prepared by mixing the solutions of 44 individual phenolic acids and flavonoids at concentration of $100 \mu \mathrm{g} / \mathrm{mL}$ each. Working standard solutions were prepared by dilution of stock solution in methanol-water $(1: 1, v / v)$ to obtain final concentrations in the range of 0.0015 to $25.0 \mu \mathrm{g} / \mathrm{mL}$. Concentrations of compounds in the extract were determined from the peak areas using the equation for linear regression obtained from the calibration curves $\left(r^{2}>0.995\right)$ and expressed as $\mu \mathrm{g} / \mathrm{g}$ dry weight.

\section{DPPH radical (DPPH) scavenging activity}

Free radical scavenging activity based on the monitoring of $\mathrm{DPPH}^{-}$radical transformation in the presence of the ethanolic extract was determined as previously described by Espin et al. [18]. Briefly, the reaction mixture in the wells consisted of the extract $(10 \mu \mathrm{L}), \mathrm{DPPH}$ solution $(60 \mu \mathrm{L})$ and methanol $(180 \mu \mathrm{L})$. The reaction mixture was incubated in the dark for $60 \mathrm{~min}$ at $25^{\circ} \mathrm{C}$. The absorbance was measured at $540 \mathrm{~nm}$ using a plate reader (Multiskan Ascent, Thermo Electron Corporation). Each sample was tested at five different concentrations in the range of $7.5-200 \mu \mathrm{g} / \mathrm{mL}$ to obtain $\mathrm{IC}_{50}$. The $\mathrm{IC}_{50}$ value $(\mu \mathrm{g} / \mathrm{mL})$ was defined as the concentration of an antioxidant extract which was required to quench $50 \%$ of the initial amount of DPPH. under the experimental conditions given.

\section{Ferric reducing antioxidant power (FRAP)}

FRAP assay was performed on the ethanolic extract according to modified procedure of Benzie et al. [19]. The FRAP reagent is a mixture of $300 \mathrm{mM}$ acetate buffer (pH 3.6): $10 \mathrm{mM} \mathrm{2,4,6-tris(2-pyridyl)-s-triazine} \mathrm{(TPTZ)}$ in $40 \mathrm{mM} \mathrm{HCl}: 20 \mathrm{mM} \mathrm{FeCl}_{3}(10: 1: 1, v / v / \mathrm{v})$. The reaction mixture in the wells consisted of the extract $(10 \mu \mathrm{L})$, FRAP reagent $(225 \mu \mathrm{L})$ and distilled water $(22.5 \mu \mathrm{L})$. Absorbance was measured at $620 \mathrm{~nm}$, after 6 min of incubation. Ascorbic acid was used to construct the standard curve and results were expressed as mg 
ascorbic acid equivalents (AAE)/g of extract on dry weight basis.

\section{Nitric oxide radical (NO) scavenging capacity}

NO scavenging capacity was determined according to the procedure of Green et al. [20]. Briefly, the reaction mixture in the test tubes consisted of the extract $(30 \mu \mathrm{L})$, sodium nitroprusside (SNP) $(500 \mu \mathrm{L})$ and $0.067 \mathrm{~mol} / \mathrm{L}$ phosphate buffer at $\mathrm{pH} 7.4(500 \mu \mathrm{L})$. Test tubes were incubated under light exposure at $25{ }^{\circ} \mathrm{C}$ for $90 \mathrm{~min}$. After incubation, Griess reagent consisting of $0.2 \%$ solution of $\mathrm{N}$-(1-naphthyl) ethylenediamine dihydrochloride (NEDA): $2 \%$ solution of sulphanilamide in $4 \%$ of phosphoric acid $(1: 1, \mathrm{v} / \mathrm{v})$ was added $(1 \mathrm{~mL})$. Aliquots of the reaction mixture $(250 \mu \mathrm{L})$ were transferred to the plate, and their absorbances were measured using a plate reader at $540 \mathrm{~nm}$ (Multiskan Ascent, Thermo Electron Corporation). Samples were tested at five different concentrations in the range of $74-591 \mu \mathrm{g} / \mathrm{mL}$ to obtain $\mathrm{IC}_{25}$, defined as the concentration of the extract which scavenges $25 \%$ of the initial amounts of $\mathrm{NO}$.

\section{Hydroxyl radical $(\mathrm{OH})$ scavenging capacity}

Determination of scavenging activity on $\mathrm{OH}^{*}$, generated in Fenton reaction, was performed from the reaction of 2-deoxyribose degradation [21]. The reaction mixture contained $100 \mu \mathrm{L}$ of 2-deoxyribose, $100 \mu \mathrm{L}$ of $\mathrm{FeSO}_{4}\left(127 \mathrm{mg} \mathrm{FeSO} \cdot 7 \mathrm{H}_{2} \mathrm{O}\right.$ in $50 \mathrm{~mL}$ of phosphate buffer, $\mathrm{pH}$ 7.4) and $10 \mu \mathrm{L}$ of the tested extract. Phosphate buffer was added to the mixture to the final volume of $3 \mathrm{~mL}$ and incubated at $37{ }^{\circ} \mathrm{C}$ for $1 \mathrm{~h}$. Two millilitres of TBA-reagent $\left(10.4 \mathrm{~mL}\right.$ of $10 \% \mathrm{HClO}_{4}$, $3 \mathrm{~g}$ of thiobarbituric acid (TBA) and $120 \mathrm{~g}$ of $20 \%$ trichloroacetic acid (TCA) dissolved in $800 \mathrm{~mL}$ of distilled $\mathrm{H}_{2} \mathrm{O}$ ) and $0.2 \mathrm{~mL}$ of $0.1 \mathrm{M}$ EDTA were added to terminate the reaction. The absorbance was measured at $532 \mathrm{~nm}$ using a UV-Vis spectrophotometer (Agilent Technologies, Santa Clara, CA). To obtain $\mathrm{IC}_{50}$ value, the range of concentrations of $0.7-4.7 \mu \mathrm{g} /$ $\mathrm{mL}$ MG extract was tested.

\section{Superoxide anion radical $\left(\mathrm{O}_{2}^{-}\right)$scavenging activity}

Superoxide anion radical scavenging activity of the ethanolic extract was determined by measuring its ability to neutralize superoxide anion radicals generated during aerobic reduction of nitro blue tetrazolium (NBT) by $\mathrm{NADH}$, mediated by 5-methylphenazin-5-ium methyl sulphate (PMS) [22]. The reaction mixture in a test tube was composed by $677 \mu \mathrm{M}$ NADH $(100 \mu \mathrm{L}), 60 \mu \mathrm{M}$ PMS $(100 \mu \mathrm{L}), 144 \mu \mathrm{M}$ NBT $(200 \mu \mathrm{L}), 0.017 \mathrm{~mol} / \mathrm{L}$ phosphate buffer at pH $8.3(1,1 \mathrm{~mL})$ and the extract $(10 \mu \mathrm{L})$. After $5 \mathrm{~min}$ of incubation, aliquots $(250 \mu \mathrm{L})$ were transferred to the plate wells (Multiskan Ascent, Thermo Electron Corporation), and their absorbances were measured at
$540 \mathrm{~nm}$. Five different concentrations of each sample in the range of $2.4-33.1 \mu \mathrm{g} / \mathrm{mL}$ were tested to obtain $\mathrm{IC}_{50}$, defined as the concentration of the extract able to scavenge $50 \%$ of $\mathrm{O}_{2}{ }^{--}$.

\section{Jurkat and HL-60 cell culture and treatments}

Jurkat cells (acute T-cell lymphoblastic leukaemia) and HL-60 cells (acute promyelocytic leukaemia) were purchased at the "Istituto Zooprofilattico" of Lombardia and Emilia-Romagna (Brescia, Italy). Both cell lines were cultured at $37{ }^{\circ} \mathrm{C}$ and $5 \% \mathrm{CO}_{2}$ in Roswell Park Memorial Institute (RPMI)1640 medium supplemented with $1 \%$ Penicillin-Streptomicin (PS), 1\% L-Glutamine (L-GLU) and $10 \%$ of Fetal Bovine Serum (FBS) for Jurkat cells and 20\% of FBS for HL-60 cells (all from Sigma Aldrich, Saint Luis, MO, USA).

The MG extract was dissolved in RPMI at $20 \%$ of DMSO $(v / v)$, in order to obtain a Working Solution $50 \mathrm{mg} / \mathrm{mL}$. The solution thus prepared has been stored for a maximum of $72 \mathrm{~h}$ at $-20{ }^{\circ} \mathrm{C}$ and protected from light. The concentrations of the different extracts tested ranged from 0 to $750 \mu \mathrm{g} / \mathrm{mL}$ and the concentration of DMSO was always within the $0.05-1 \%$ range in all experimental conditions.

In particular, $3.75 \times 10^{5}$ of Jurkat cells were treated with increasing concentrations of extract from 0 to $500 \mu \mathrm{g} / \mathrm{mL}$ and incubated for 24,48 and $72 \mathrm{~h}$. The cell density never exceeded the critical value of $3.00 \times 10^{6}$ cells $/ \mathrm{mL}$ of medium. One hundred twenty-five thousand of HL-60 cells were treated with increasing concentrations of extracts from 0 to $750 \mu \mathrm{g} / \mathrm{mL}$ and incubated for 24, 48 and $72 \mathrm{~h}$. The cell density never exceeded the critical value of $1.00 \times 10^{6}$ cells $/ \mathrm{mL}$ of medium.

\section{PBL culture and treatments}

Authorization to the use of human blood samples (Buffy coat), for research purposes, was obtained from AUSL of Bologna, Italy, S. Orsola-Malpighi Hospital -PROT GEN No. 0051937, and written informed consent was obtained by AUSL of Bologna, Italy, S. Orsola-Malpighi Hospital from donors for the use of their blood for scientific research purposes. PBL were isolated from the whole peripheral blood of 5 AVIS healthy donors (Association of Italian Blood Volunteers), by density gradient centrifugation with Histopaque-1077 (Sigma Aldrich, Saint Luis, MO, USA) [23].

PBL were cultured at $37{ }^{\circ} \mathrm{C}$ and $5 \% \mathrm{CO}_{2}$ in RPMI1640 supplemented with $1 \%$ PS, $1 \%$ L-GLU, 15\% FBS and in the presence of $0.5 \%$ Phitohemagglutinin (PHA) (Sigma Aldrich, Saint Louis, MO, USA) for $48 \mathrm{~h}$ to stimulate cell proliferation. Two hundred thousand PBL were than treated with increasing concentrations of extract from 0 to $1000 \mu \mathrm{g} / \mathrm{mL}$ and incubated for $24 \mathrm{~h}$. 


\section{Flow cytometry (FCM)}

All FCM analyzes reported below were performed using a Guava easyCyte $5 \mathrm{HT}$ flow cytometer equipped with a class IIIb laser operating at $488 \mathrm{~nm}$ (Merck, Darmstadt, Germany).

\section{Cytotoxicity analysis by FCM}

The cytotoxicity induced by MG was evaluated by the Guava ViaCount Assay protocol. In particular, the percentage of viable cells was assessed by FMC using the Guava ViaCount Reagent (Merck, Darmstadt, Germany) that contains the dye Propidium Iodide (PI) and analyzed by Guava ViaCount software [24].

The results obtained in the samples treated with different concentrations of extracts were normalized on those obtained in control cultures and used to calculate the $\mathrm{IC}_{50}$ by interpolation from the dose-response curve. In the subsequent experiments concentrations $\leq \mathrm{IC}_{50}$ were used.

\section{Analysis of apoptosis by FCM and optical microscopy} The discrimination of the death mechanism was assessed by the Guava Nexin Assay Protocol. In particular, the percentage of live, apoptotic and necrotic cells was assessed by FCM using the Guava Nexin Reagent (Merck, Darmstadt, Germany) that containing 7-aminoactinomycin D (7-AAD) and Annexin-V-PE and analyzed by Guava Nexin software as previously reported [24, 25].

Moreover, the nuclear condensation and fragmentation associated with the apoptotic process was evaluated by fluorescence microscopy with $100 \mathrm{X}$ magnification. After treatment, $1.00 \times 10^{6}$ cells were loaded into cytospin chamber and centrifuged ad $450 \mathrm{rpm}$ for $10 \mathrm{~min}$. Cells were than fixed in formaldehyde 3.7\%, washed in PBS pH 7.2, permeabilized in 0.15\% triton X-100 (all Sigma-Aldrich, Saint Louis, MO, USA) and nuclei were stained using Hoechst $33342500 \mathrm{nM}$ as previously reported [26].

\section{Cell-cycle analysis by FCM}

The effect of MG on the cancer cells replication was evaluated by GUAVA Cell-Cycle Assay protocol. In particular, the percentage of cells in the different phases of the cell-cycle $\left(G_{0} / G_{1}, S, G_{2} / M\right)$ was assessed by FCM using the Cell-Cycle Reagent (Merck, Darmstadt, Germany) that containing PI and analysed by Guava Cell-Cycle software [24].

\section{RNA extraction}

After $16 \mathrm{~h}$ treatments, total RNA was extracted from Jurkat and HL-60 cells by using RNeasy Mini Kit (QIAGEN GmbH, Hilden, Germany), following the manufacturer's protocol. The yield and purity of the RNA were measured using NanoVue Spectrophotometer (GE Healthcare, Milan, Italy).

\section{Analysis of FAS, BAX and BCL2 mRNA expression levels by reverse transcriptase polymerase chain reaction} cDNA was obtained by reverse transcribing mRNA starting from $1 \mu \mathrm{g}$ of total RNA using iScript cDNA Synthesis Kit (BIO-RAD, Hercules, CA, USA), following the manufacturer's protocol. The subsequent polymerase chain reaction (PCR) was performed in a total volume of $10 \mu \mathrm{l}$ containing $2.5 \mu \mathrm{l}(12.5 \mathrm{ng})$ of cDNA, $5 \mu \mathrm{l}$ SsoAdvanced Universal SYBR Green Supermix (BIO-RAD, Hercules, CA, USA) and $0.5 \mu \mathrm{l}(500 \mathrm{nM})$ of each primer. The primers used are reported in Table 1 18S rRNA and GAPDH were used as reference genes.

\section{Intracellular ROS level}

After $24 \mathrm{~h}$ treatment Jurkat and HL-60 cells $\left(1.00 \times 10^{6}\right.$ cells $/ \mathrm{mL}$ ), were washed twice in HBSS, and incubated with $5 \mu \mathrm{M} \quad 2^{\prime}-7^{\prime}$-dichlorodihydrofluorescin diacetate (DCFH-DA) (Sigma-Aldrich, Saint Louis, MO, USA), for 20 min at $37{ }^{\circ} \mathrm{C}$. When inside the cell, DCFH-DA is deacetylated and can be oxidized by ROS to the highly fluorescent $2^{\prime}, 7^{\prime}$-dichlorofluorescein (DCF). DCF fluorescence was measured using a multi-well plate reader (Wallac Victor2, PerkinElmer) at excitation and emission wavelengths of 485 and $535 \mathrm{~nm}$, respectively [27]. Fluorescence values were reported as percentage of intracellular ROS with respect to control.

\section{Statistical analysis}

Results on TP and TF content, on DPPH, $\mathrm{OH}^{*}, \mathrm{O}_{2}{ }^{*-}$, NO scavenging activity and FRAP are expressed as mean \pm standard deviation (SD). All results on cell viability, analysis of apoptosis, cell-cycle, gene expression and intracellular ROS are expressed as mean \pm standard error mean (SEM) of at least five independent experiments. For the statistical analysis of apoptosis, cell-cycle and gene expression level we used the Analysis of Variance for paired data (repeated ANOVA), followed by Bonferroni as the post-test. For statistical analyses of ROS intracellular level we used the $\mathrm{t}$-test for paired data. All the statistical analyses

Table 1 Both forward and reverse primer sequences for BAX, BCL2, FAS, GAPDH and 185 rRNA genes are reported

\begin{tabular}{lll}
\hline Gene & 5'-Forward-3' & 5'-Reverse-3' \\
\hline BAX & AACTGGACAGTAACATGGAG & TTGCTGGCAAAGTAGAAAAG \\
BCL2 & GATTGTGGCCTTCTTTGAG & GTTCCACAAAGGCATCC \\
FAS & CTGTCCTCCAGGTGAAAG & TGTACTCCTTCCCTTCTTG \\
GAPDH & ACAGTTGCCATGTAGACC & TTGAGCACAGGGTACTTTA \\
18S rRNA & CAGAAGGATGTAAAGGATGG & TATTTCTTCTTGGACACACC \\
\hline
\end{tabular}


were performed using GraphPad Software Prism 6 (GraphPad Software LLC, La Jolla, CA, USA).

\section{Results}

\section{MG phenolic composition}

TP content of MG ethanolic extract resulted in $106.33 \pm$ $11.27 \mathrm{mg} \mathrm{GAE} / \mathrm{g}$ extract, while TF content resulted in $13.84 \pm 1.11 \mathrm{mg} \mathrm{QE} / \mathrm{g}$ extract. HPLC-MS/MS analyses revealed the presence of $p$-OH-benzoic acid, protocatechuic acid, $p$-coumaric acid and caffeic acid. Quantitative determination is reported in Table 2 .

\section{Antioxidant activity of MG extract}

Since different mechanisms are involved in the neutralization of different radical species Table 3 reports the antioxidant activity of MG extract measured according to five methods, $\mathrm{DPPH}, \mathrm{NO}, \mathrm{OH}^{-}$and $\mathrm{O}_{2}{ }^{--}$scavenging capacity and FRAP.

\section{Cytotoxicity analysis on Jurkat and HL-60 cells}

After $24 \mathrm{~h}$ treatment the $\mathrm{IC}_{50}$ for $\mathrm{MG}$ was found to be $385 \mu \mathrm{g} / \mathrm{mL}$ in Jurkat cells and equal to $461 \mu \mathrm{g} / \mathrm{mL}$ in HL-60 (Fig. 1).

\section{Apoptosis analysis on Jurkat and HL-60 cells}

In order to evaluate the involvement of a specific cell death mechanism in the demonstrated cytotoxic action, the analysis of apoptosis possibly induced at different concentrations on Jurkat and HL-60 cells was performed, after 24, 48 and $72 \mathrm{~h}$, in order to determine if the event was dose and/or time-dependent.

Specifically, the cells were treated with concentrations $\leq \mathrm{IC}_{50}$ and the double staining Annexin V-PE / 7-AAD allowed to measure the percentage of live, apoptotic and necrotic cells.

In Jurkat cells, MG showed a dose- and time-dependent induction of apoptosis. In fact after $24 \mathrm{~h}$ there was a statistically significant increase of apoptotic cells percentage at the concentration $125 \mu \mathrm{g} / \mathrm{mL}$ equal to 2 times compared to the control $(7.3 \%$ vs $3.1 \%)$ and an increase equal to 3 times at $250 \mu \mathrm{g} / \mathrm{mL}(8.4 \%$ vs $3.1 \%)$. After $48 \mathrm{~h}$, on the other hand, a doubling of the fraction of apoptotic cells compared to $24 \mathrm{~h}$ was

Table 2 Content of phenolic compounds in MG extract

\begin{tabular}{ll}
\hline Phenolic compounds & $\mu \mathrm{g} / \mathrm{g}$ dry weight \\
\hline p-OH-benzoic acid & $23.9 \pm 3.66$ \\
Protocatechuic acid & $1.26 \pm 0.13$ \\
p-coumaric acid & $0.2 \pm 0.05$ \\
Caffeic acid & $1.3 \pm 0.11$
\end{tabular}

Values are expressed as means \pm SD of triplicate measurements. Phenolic acid contents were determined by HPLC-MS/MS as described in the Methods section
Table 3 Antioxidant activity of MG extract

\begin{tabular}{ll}
\hline DPPH $\left(I C_{50}\right)^{\mathrm{a}} \mu \mathrm{g} / \mathrm{mL}$ & $57.77 \pm 2.48$ \\
\hline $\mathrm{NO} \cdot\left(\mathrm{IC}_{25}\right)^{\mathrm{b}} \mu \mathrm{g} / \mathrm{mL}$ & $148.04 \pm 4.98$ \\
$\mathrm{OH}\left(\mathrm{IC}_{50}\right)^{\mathrm{a}} \mu \mathrm{g} / \mathrm{mL}$ & $1.74 \pm 0.2$ \\
$\mathrm{O}_{2}^{-}\left(\mathrm{IC}_{50}\right)^{\mathrm{a}} \mu \mathrm{g} / \mathrm{mL}$ & $24.28 \pm 2.06$ \\
FRAP $^{\mathrm{C}} \mathrm{mg}(\mathrm{AAE}) / \mathrm{g}$ & $22.54 \pm 3.51$
\end{tabular}

Values are expressed as means \pm SD of triplicate measurements. Antioxidant activity was determined as described in the Methods section

${ }^{\mathrm{a}} \mathrm{I}_{50}(\mu \mathrm{g} / \mathrm{mL})$, concentration of extract that neutralized $50 \%$ of $\mathrm{DPPH} \cdot \mathrm{OH}$. and $\mathrm{O}_{2}$

${ }^{\mathrm{b}} \mathrm{IC}_{25}(\mu \mathrm{g} / \mathrm{mL})$, concentration of extracts that neutralized $25 \%$ of $\mathrm{NO}$

${ }^{C}$ Ferric reducing antioxidant power (FRAP) is expressed as $\mathrm{mg}$ ascorbic acid equivalents/g extract dry weight (mg AAE/g d.w)

observed at both concentrations tested. Specifically there was a 4 times increase at $125 \mu \mathrm{g} / \mathrm{mL}(13.3 \%$ vs $3.5 \%)$ and a 6 times increase at $250 \mu \mathrm{g} / \mathrm{mL}(21.2 \%$ vs $3.5 \%$ ). At $72 \mathrm{~h}$ the trend is comparable (Fig. 2a, b, c).

In HL-60 (Fig. 3) after $24 \mathrm{~h}$ there was evidence at the concentration of $125 \mu \mathrm{g} / \mathrm{mL}$, a statistically significant increase in the fraction of apoptotic cells, equal to 3 times compared to control (11.3\% vs. $3.8 \%)$, parallel to an
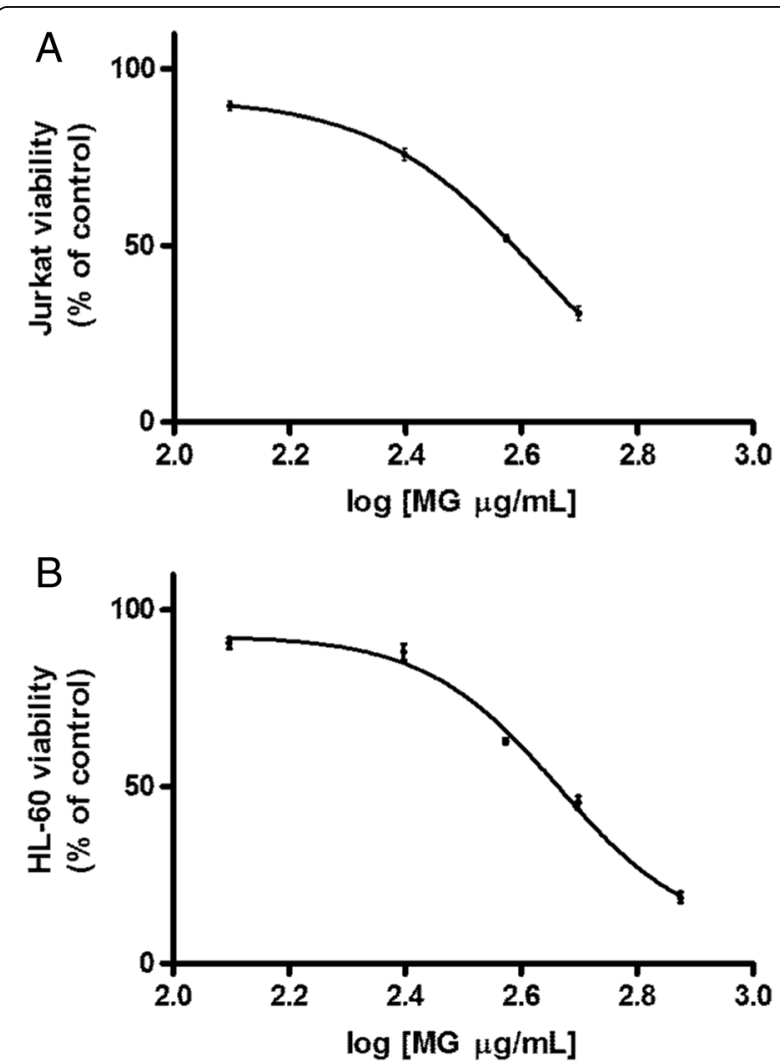

Fig. 1 Effect of MG on viability of Jurkat and HL-60 cells. Cell viability was determined as described in Methods section. $I C_{50}$ obtained by curve fitting of viable cells after $24 \mathrm{~h}$ treatment with MG for Jurkat cells (a) and HL-60 cells (b). Data are presented as means \pm SEM of five independent experiments 
increase of 3 and 4 times, for $250 \mu \mathrm{g} / \mathrm{mL}$ and $375 \mu \mathrm{g} /$ $\mathrm{mL}$, respectively $(11.1 \%$ vs. $3.8,16.2 \%$ vs $3.8 \%)$. After $48 \mathrm{~h}$, the trend remained comparable to $24 \mathrm{~h}$ for the $125 \mu \mathrm{g} / \mathrm{mL}$ concentration ( $11.6 \%$ vs $3.7 \%$ ), while for $250 \mu \mathrm{g} / \mathrm{mL}$ a further increase in the number of apoptotic cells was observed, equal to at 4 times the control $(15.2 \%$ vs. $3.7 \%)$; the same concentration, at the longest treatment time (72 h), was instead associated with an increase equal to 6 times (8.6\% vs $1.4 \%$ ). Therefore, these data demonstrate a dose- and time-correlated trend at all times analysed, particularly evident for the concentration of $250 \mu \mathrm{g} / \mathrm{mL}$.

Considering the demonstrated pro-apoptotic effect, we wanted to confirm the results obtained by FCM, also by fluorescence microscopy analysis, visualizing the morphological changes characteristic of apoptosis, such as nuclear condensation and fragmentation (Fig. 4).

\section{Cell-cycle analysis on Jurkat and HL-60 cells}

In order to evaluate whether the induction of apoptosis caused by MG was an independent event or subsequent a slowing/blocking of the cell-cycle, the Jurkat and HL-60 cells were treated with the concentration selected on the basis of the results obtained from the apoptosis analysis and incubated at the same treatment times. The PI staining allowed to highlight that MG does not show any activity on the cell-cycle of Jurkat cells, at the tested concentration $(250 \mu \mathrm{g} /$ $\mathrm{mL}$ ), at any treatment time (Fig. 5a, b, c).

Conversely, on HL-60 cells, after $24 \mathrm{~h}$ a slowing of the cell-cycle is observed in the $\mathrm{G}_{2} / \mathrm{M}$ phase, underlined by an increase in the cell fraction equal to a $33.1 \%$ vs $25.2 \%$ in the control cultures. At $48 \mathrm{~h}$ instead, there was an increase in the number of cells in the $G_{0} / G_{1}$ phase $(47.7 \%$ vs $35.1 \%$ ), with a consequent reduction in $\mathrm{S}$ phases (30.0\% vs $40.4 \%)$ and $\mathrm{G}_{2} / \mathrm{M}(21.8 \%$ vs $24.5 \%)$; the same behaviour is observed at $72 \mathrm{~h}$ (Fig. 6a, b, c).

FAS, BAX and BCL2 expression analysis on Jurkat and HL60 cells

mRNA expression analysis of three genes involved in apoptotic pathways regulation such as FAS, BAX, BCL2 were performed.

Figure 7 shows that MG extract after $16 \mathrm{~h}$ treatment significantly induced, in both Jurkat and HL-60, FAS mRNA expression level (Fig. 7a, c) and increases the ratio between BAX and BCL2 mRNA expression (Fig. 7b, d).

\section{Intracellular ROS level}

To characterize the mechanism behind MG capability to induce apoptosis in leukaemia cells its potential modulatory effect on intracellular ROS level was investigated in both Jurkat and HL-60 cells by the DCFH-DA assay. As
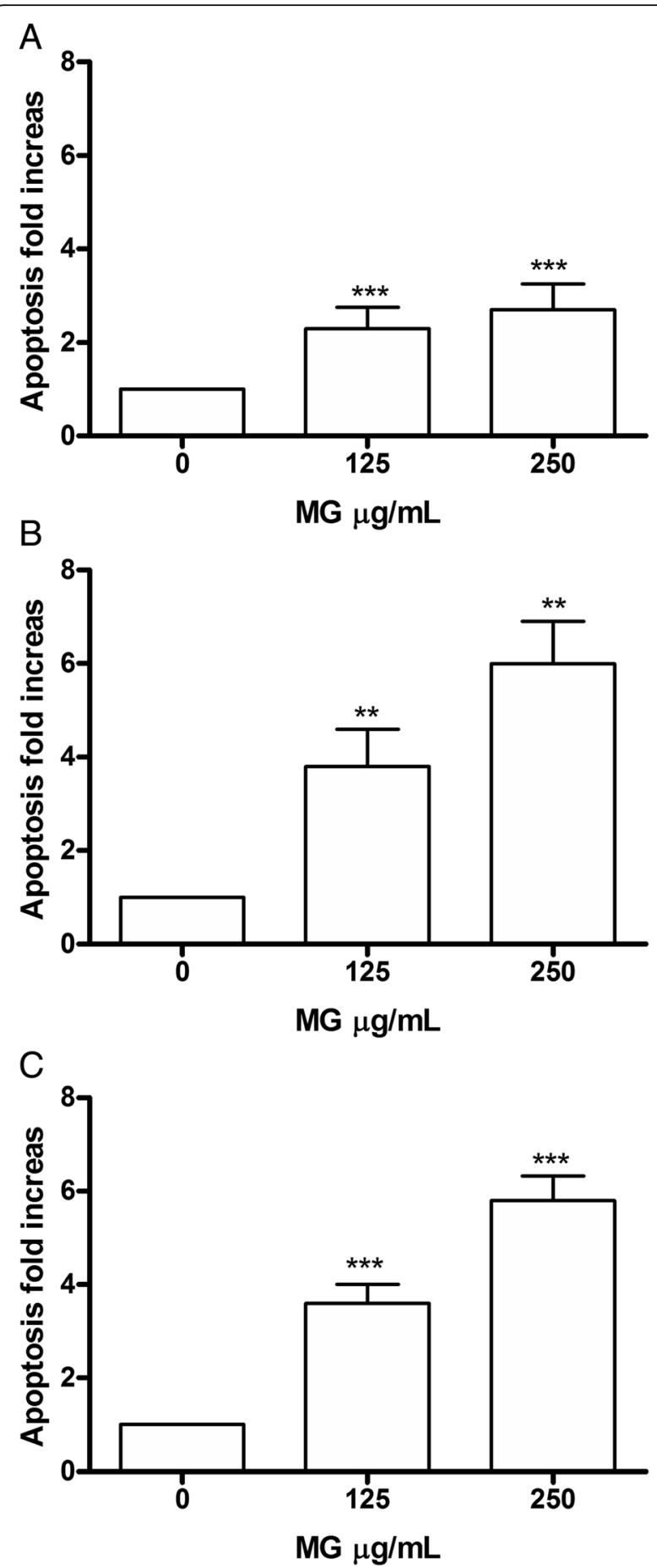

Fig. 2 Increase in apoptotic Jurkat cell fraction after MG treatment. Apoptosis was evaluated at $24 \mathrm{~h} \mathrm{(a),48} \mathrm{h} \mathrm{(b)} \mathrm{and} 72 \mathrm{~h} \mathrm{(c)}$ ), as reported in Methods section. Each bar represents means \pm SEM of five independent experiments. Data were analysed using repeated ANOVA followed by Bonferroni post-test. $p<0.01$ vs control; ${ }^{* * *} p<$ 0.001 vs control 


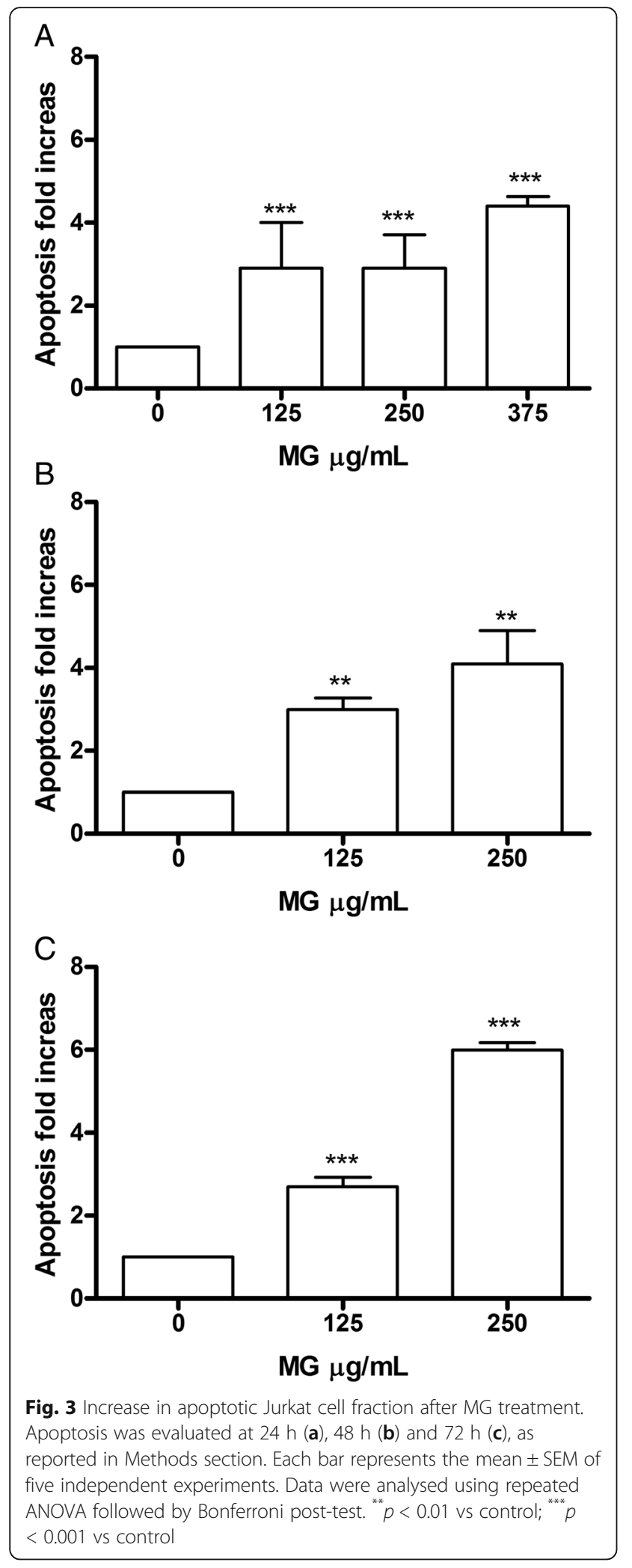

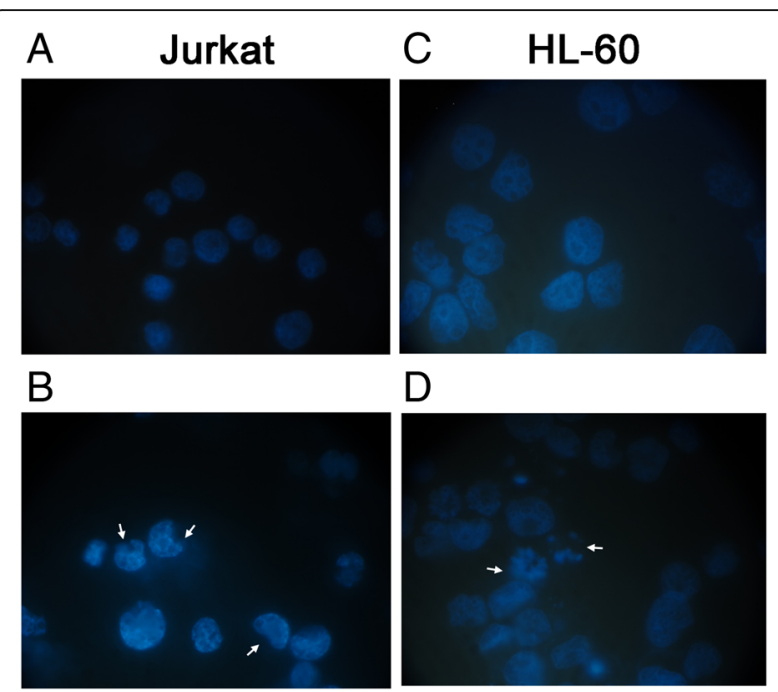

Fig. 4 Fluorescence microscopy analysis of Jurkat and HL-60 after MG treatment. Nuclear condensation and fragmentation associated to apoptotic process on Jurkat and HL-60 cells was evaluated by fluorescence microscopy at 100x magnification after $24 \mathrm{~h}$ of $250 \mathrm{\mu g} /$ $\mathrm{mL} M \mathrm{MG}$ treatment $(\mathbf{b}, \mathbf{d})$ respect to control culture $(\mathbf{a}, \mathbf{c})$. White arrows indicate condensed and/or fragmented nuclei as marker of apoptosis

shown in Fig. 8, ROS intracellular level was significantly decreased respect to control by MG $250 \mu \mathrm{g} / \mathrm{mL}$ after $24 \mathrm{~h}$ treatment in both cell-lines.

\section{Cytotoxicity analysis on PBL}

The analysis of the viability of PBL following MG treatment for $24 \mathrm{~h}$ allowed to obtain an $\mathrm{IC}_{50}$ value of $761 \mu \mathrm{g} /$ $\mathrm{mL}$, which demonstrated a cytotoxicity lower than that manifested on the two leukaemia cell lines (Fig. 9).

\section{Discussion}

Great attention has been dedicated to the potential of many extracts and naturally occurring compounds in the prevention/counteraction of chronic diseases [28-30]. Numerous studies have demonstrated that molecules that exhibit antioxidant properties such as polyphenols, isothiocyanates and other compounds counteract cardiovascular, neurodegenerative diseases and the carcinogenic process at various levels by acting through multiple mechanisms [31-34]. Extracts from plant origin may contain various compounds with useful biological properties, thus configuring themselves as complex mixtures with multi-target activities, capable of inhibiting or modulating simultaneously numerous critical targets $[25,35,36]$.

Edible mushrooms, including MG, possess antioxidant, antimicrobial and anti-inflammatory properties [7, 3739], suggesting their potential application as chemopreventive agents. The purpose of this work was, therefore, 


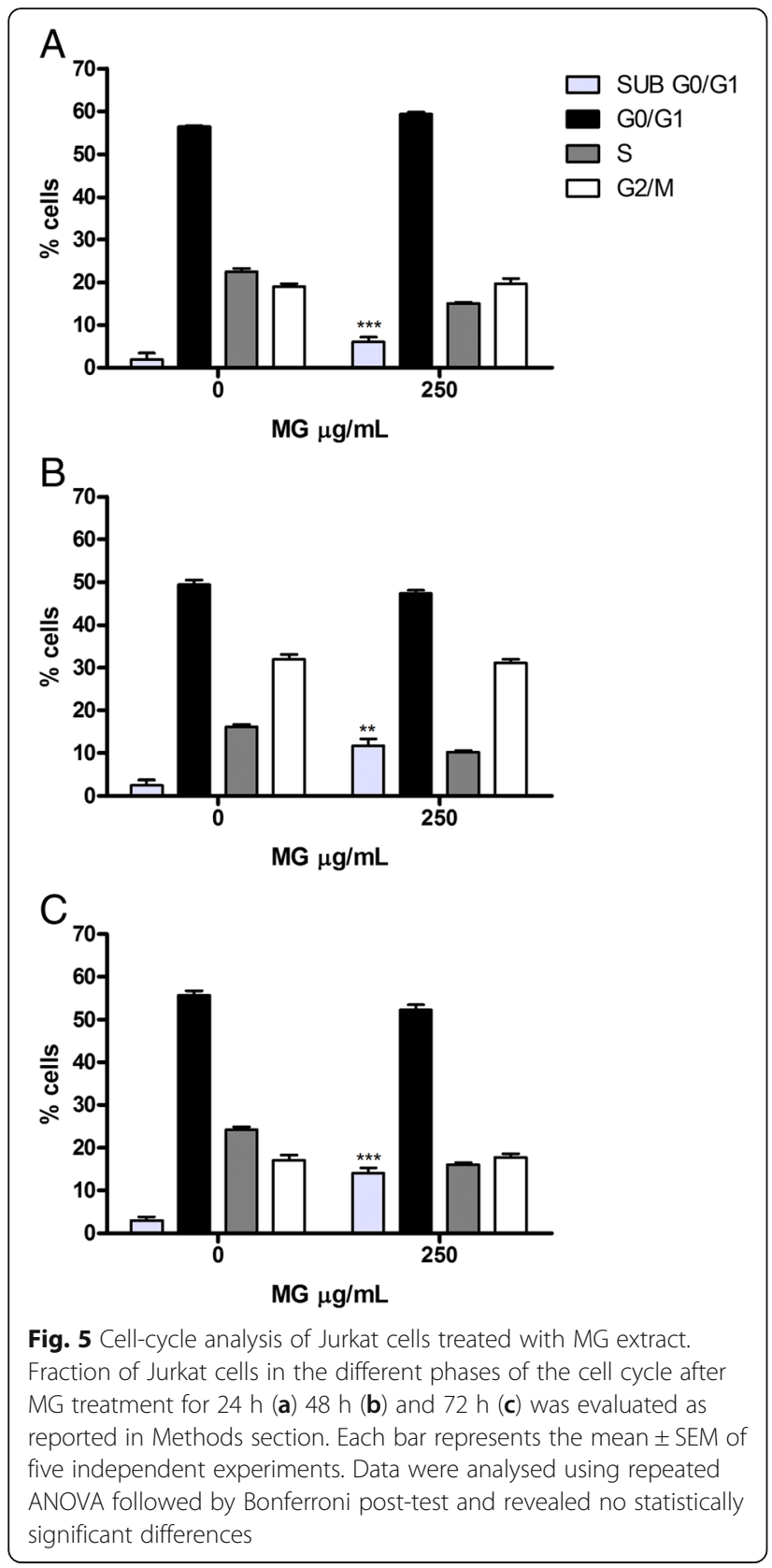

to evaluate whether MG extract is able, thanks to its antioxidant activity to exhibit chemopreventive activities. The research focused on the evaluation of numerous in vitro end-points in two leukemic cell lines (Jurkat and HL-60 cells) and subsequently in healthy lymphocytes (PBL).

Among scientific literature, strong discrepancies can be observed when comparing $\mathrm{TP}$ and $\mathrm{TF}$ content of MG extracts., These differences are probably due to extraction methods, mushroom provenance and the fact that TP and TF might be expressed in different ways. Papers reporting the TP of wild edible mushrooms other than MG differ in a very wide range in the order of $\mathrm{mg} / \mathrm{mL}[6,40-42]$.
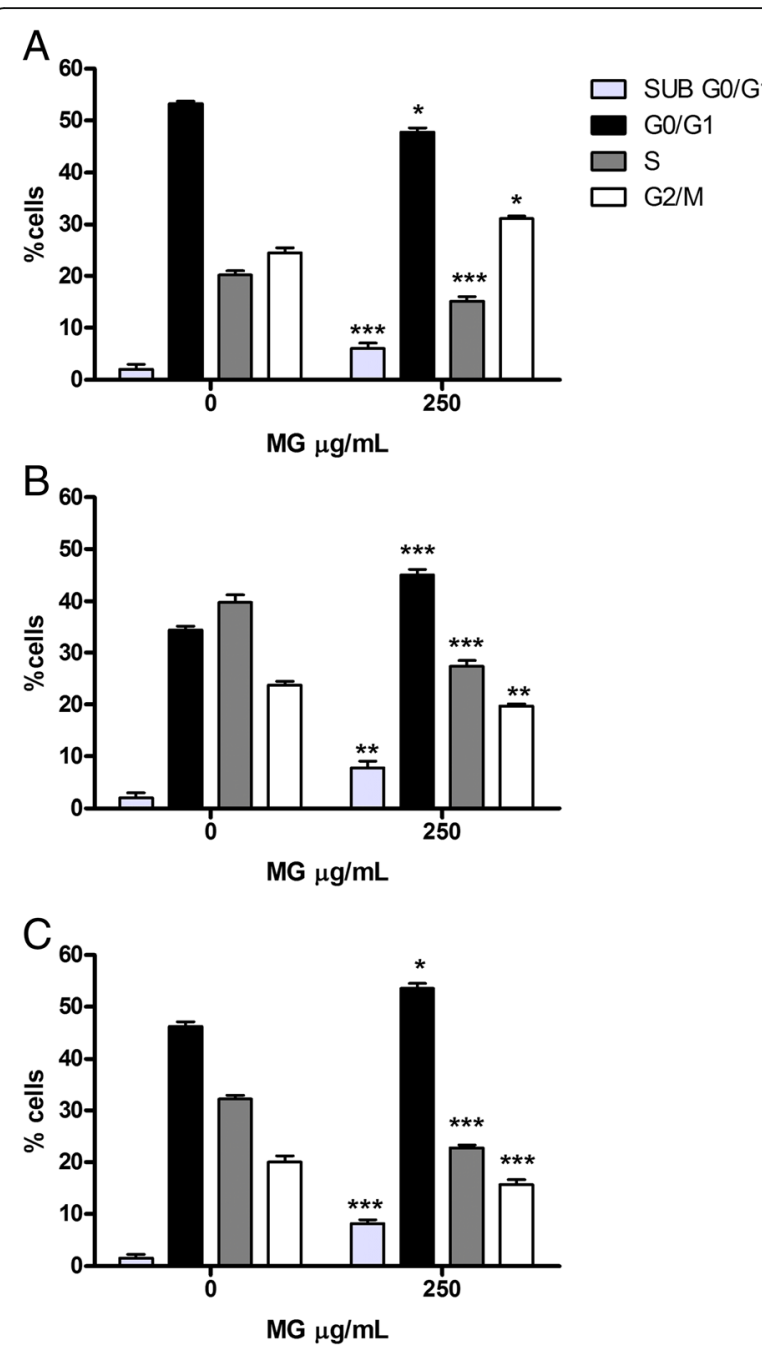

Fig. 6 Cell-cycle analysis of HL-60 cells treated with MG extract. Fraction of HL-60 cells in the different phases of the cell-cycle after MG treatment for $24 \mathrm{~h} \mathrm{(a)} 48 \mathrm{~h}$ (b) and $72 \mathrm{~h}$ (c) was evaluated as reported in Materials and Methods section. Each bar represents the mean \pm SEM of five independent experiments. Data were analysed using repeated ANOVA followed by Bonferroni post-test. ${ }^{*} p<0.05$ vs control; ${ }^{* *} p<0.01$ vs control; ${ }^{* * *} p<0.001$ vs control

HPLC-MS/MS analysis of MG ethanolic extract resulted in quantification of four phenolic acids, giving the total sum of $26.66 \mu \mathrm{g} / \mathrm{g}$. Dominant phenolic acid was $p$-hydroxybenzoic acid, in accordance with previously published data on MG [6]. All the differences that can be observed when comparing the previously published data for MG and other wild mushrooms should be attributed to the changes that occur during the mushrooms harvest and postharvest period of time, due to the enzymatic and oxidative processes [43, 44].

It has been shown that the strong antiradical activity of mushroom extracts on different radical species is due to the presence of different phenolic compounds and flavonoids $[45,46]$. 

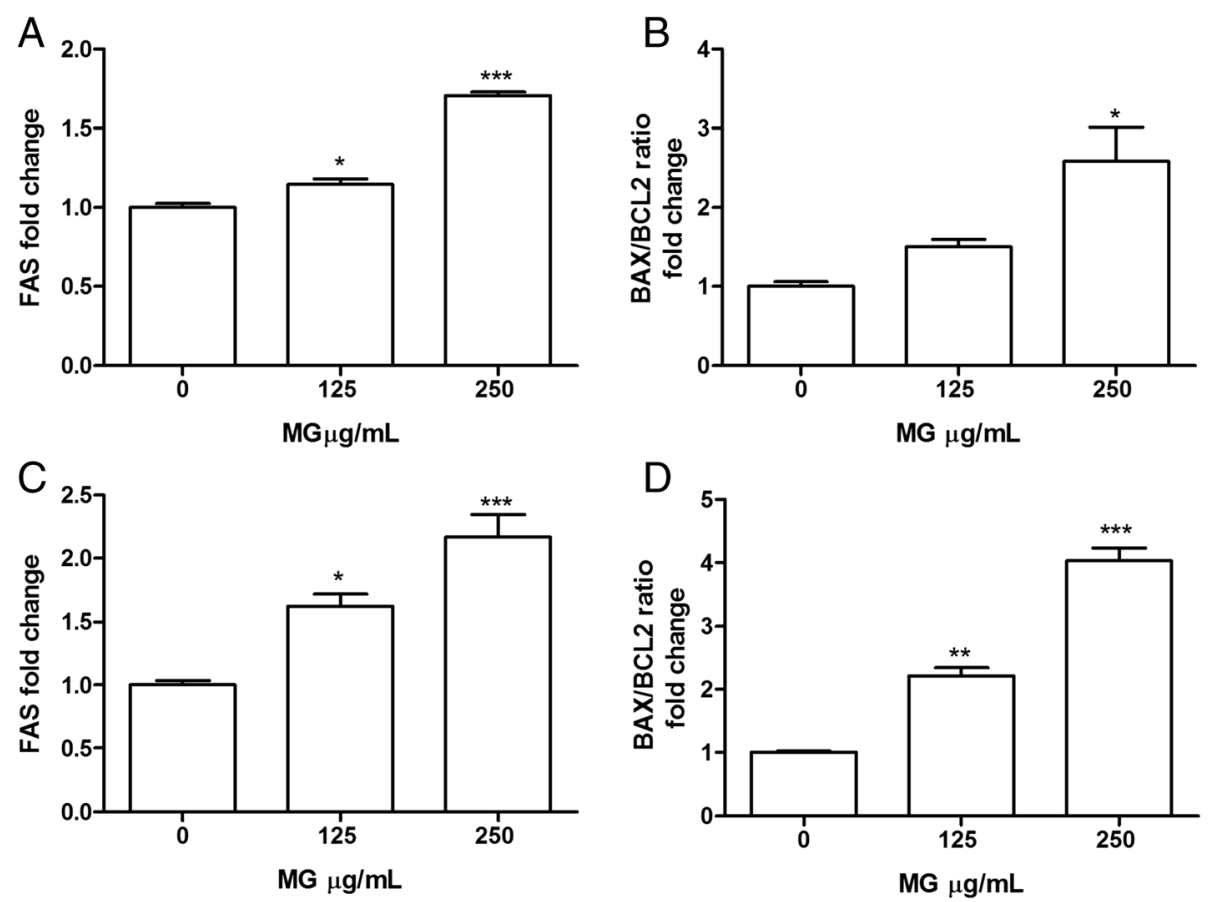

Fig. 7 Effect of MG extract treatment on FAS, BAX and BCL2 expression level in Jurkat $(\mathbf{a}, \mathbf{b})$ and HL-60 (c, d) cells. Total RNA was isolated, and the mRNA level of target genes was quantified using RT-PCR normalized to $18 \mathrm{~S}$ rRNA and GAPDH as reference genes. Triplicate reactions were performed for each experiment. Each bar represents the mean \pm SEM of three independent experiments. Data were analysed by one-way ANOVA followed by Bonferroni's test. ${ }^{*} p<0.05$ vs control; ${ }^{* *} p<0.01$ vs control; $p<0.001$ vs control

Determination of DPPH' scavenging capacity is a commonly employed assay in antioxidant studies, Ferreira et al. [47] analysed DPPH' scavenging capacity of different mushroom methanolic extracts finding that $\mathrm{DPPH} \mathrm{EC}_{50}$ was in the range of $8-50 \mathrm{mg} / \mathrm{mL}$. Similarly, Puttaraju et al. [48] analysed methanolic and water extracts of 23 different edible mushrooms and found that $\mathrm{DPPH} \mathrm{EC}_{50}$ values were in the same order of magnitude.

Only few studies have previously evaluated MG extracts antioxidant activity. Our data show MG ethanolic extract ability to scavenge different radicals such as

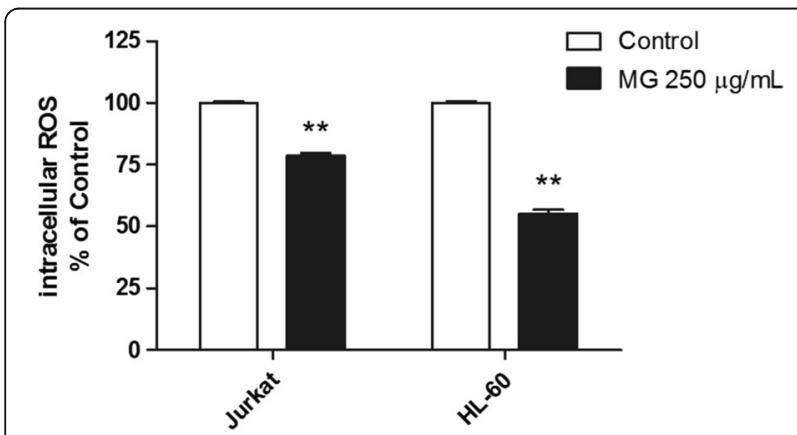

Fig. 8 Intracellular ROS level in Jurkat and HL-60 cells treated with MG at $250 \mu \mathrm{g} / \mathrm{mL}$ for $24 \mathrm{~h}$. Each bar represents the mean \pm SEM of three independent experiments. Data were analysed by t-test, ${ }^{* *} p<0.01$ vs control
DPPH, $\mathrm{O}_{2}^{--}, \mathrm{OH}, \mathrm{NO}$ and to exert antioxidant activity by reducing $\mathrm{Fe}^{3+}$ ions (FRAP). These data are in agreement with those previously published $[5,6,8]$ which found that MG water, ethanolic, methanolic and chloroformic extracts exert $\mathrm{DPPH}^{\circ}$ and $\mathrm{OH}^{-}$radical scavenging activity with $\mathrm{EC}_{50}$ values in the order of $\mu \mathrm{g} / \mathrm{mL}$. Similarly, FRAP result is in agreement with previous report [6]. All together, these data suggest that MG extract is characterized by a strong radical scavenging activity

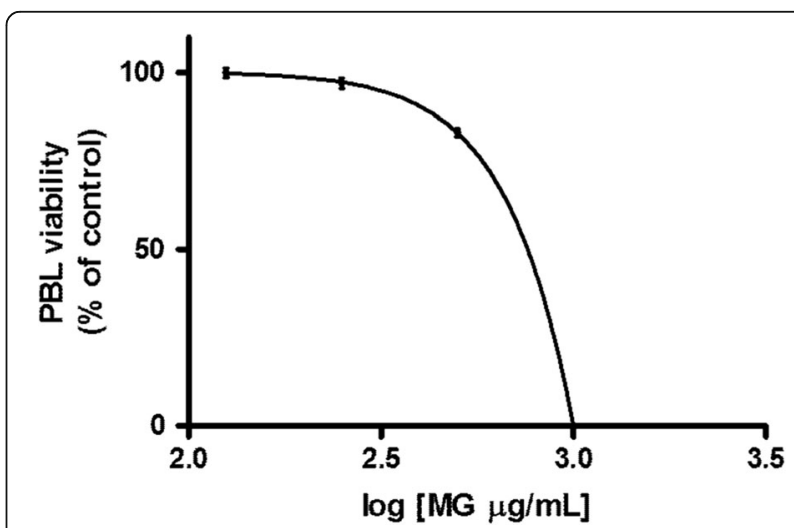

Fig. 9 Effect of MG on viability of PBL. IC $C_{50}$ was obtained by curve fitting of viable cells after $24 \mathrm{~h}$ treatment. Data are presented as mean \pm SEM of five independent experiments 
mainly related to its phenols content as previously reported by Karaman et al. [6].

Due to the strong antioxidant activity, it was possible to hypothesize a chemopreventive role for MG ethanolic extract.

A chemopreventive agent can act in different ways: by modulating the biotransformation enzymes involved in the activation/detoxification processes of carcinogens or by stimulating apoptosis and inhibiting the proliferation of transformed cells [49].

Even though some studies reporting pro-apoptotic and anti-proliferative effects of mushroom extract have already been published $[50,51]$, to our knowledge no data on MG effects in leukemic cell lines are available. Therefore, specific mechanisms of cell death, apoptosis and/or necrosis and MG ability to modulate cell-cycle were investigated.

Results show that MG is able to significantly induce apoptosis in a dose- and time- related manner in both leukemic cell lines. Moreover, it does not modulate, in any way, Jurkat cell-cycle while it inhibits HL-60 proliferation by causing a slowdown in $G_{2} / M$ phase after $24 \mathrm{~h}$ treatment, which results in a real block after $48 \mathrm{~h}$ in $G_{0} / G_{1}$ phase with a corresponding decrease in the percentage of cells in phase $S$ and $G_{2} / M$. This effect is confirmed after $72 \mathrm{~h}$ of treatment. These data are in agreement with previous reports showing that different flavonoids and polyphenols exert cell-cycle arrest in HL-60 [52]. A possible hypothesis to explain the differences between MG treatment effect on Jurkat and HL-60 cell cycle resides in the substantial differences that exist between these two cell lines. Jurkat cells are a lymphocyte cell line in an advanced state of maturation and differentiation, while HL-60 are a highly undifferentiated immature promyelocytic cell line. Future studies are needed to clarify whether these differences are responsible for the different effect of MG on the cell cycle [53].

In order to elucidate which mechanism is responsible for the pro-apoptotic effect we evaluated the expression level of genes such as FAS, BAX and BCL2.

FAS receptor belongs the family of death receptors, it is located on the cell membrane and the binding to its ligand leads to apoptosis through caspase- 8 activation which directly activates caspase 3 and simultaneously promote Bid cleavage leading to mitochondrial membrane potential loss [54]. Moreover, it has been demonstrated that FAS over-expression induces apoptosis in Jurkat cell and other malignant T-cell lines [55]. In our study, $16 \mathrm{~h}$ treatment with MG induced FAS mRNA expression in both Jurkat and HL-60 cells. Bax and Bcl-2 are mitochondrial proteins, while Bax exhibits pro-apoptotic activity, $\mathrm{Bcl}-2$ is considered an anti-apoptotic and is often overexpressed in different cancers [56, 57]. In order to induce apoptosis in cancer cells, most therapies are based on stimulating the expression of $\mathrm{Bax}$ and/or suppressing $\mathrm{Bcl}-2$ protein. In this study we contemporaneously observed, in Jurkat cells, an increase of BAX and a decrease of BCL2 gene expression level after $250 \mu \mathrm{g} / \mathrm{mL}$ MG treatment. Otherwise, in HL-60 cells a reduction of BCL2 level was found, while BAX was not affected. Our data demonstrate that BAX/ BCL2 mRNA expression ratio significantly increased in both cell lines suggesting the involvement of these two proteins in the progression of the apoptotic cascade induced by MG.

It is known, that high ROS intracellular level is a common characteristic of leukaemic and other cancer cells [58]. This feature has been observed in numerous

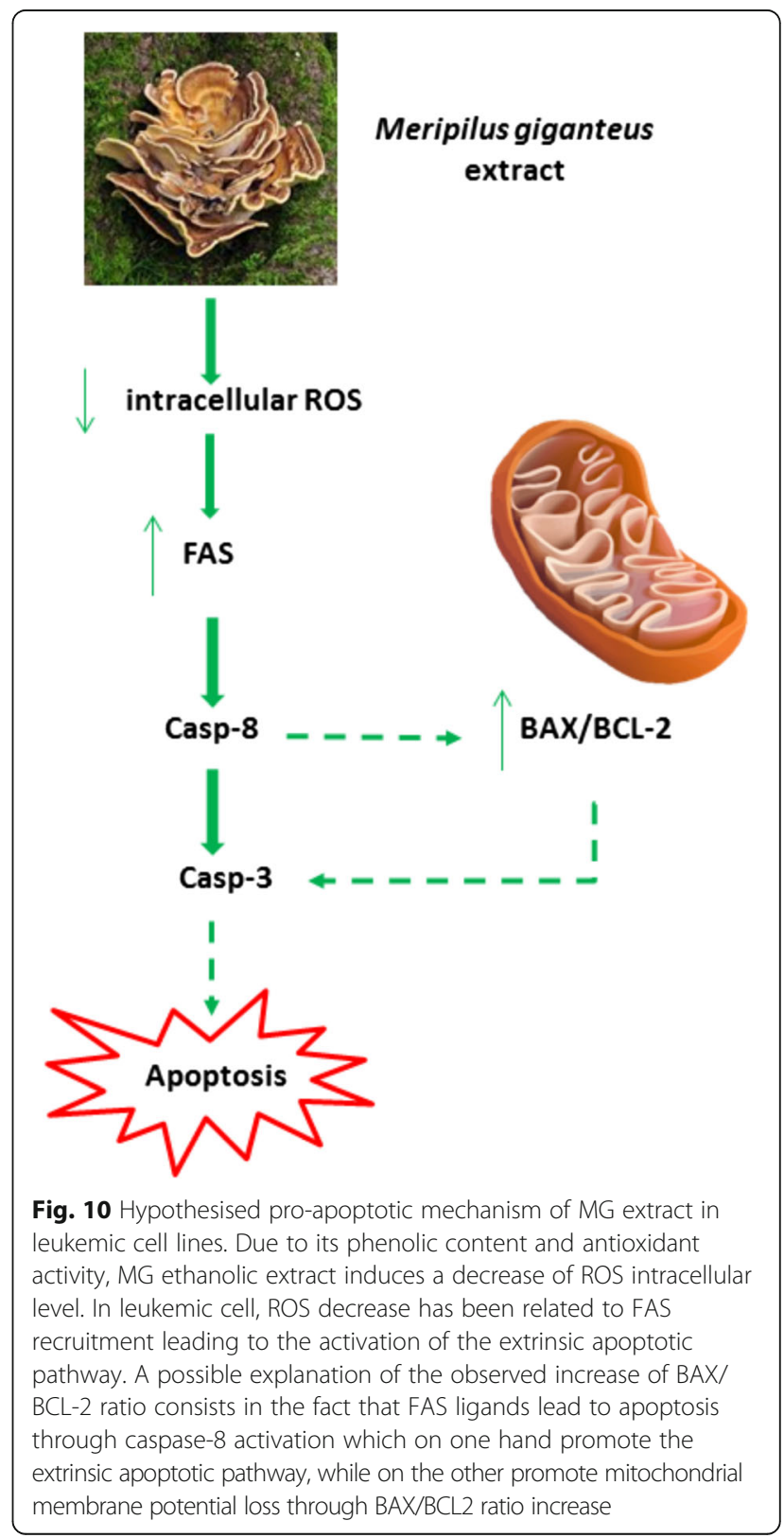


leukaemic cell lines and also in cells from patients with different types of leukaemia [59]. Therefore, it is generally accepted that increased ROS production is important for the proliferation of hematological malignancies $[60,61]$. Due to ROS importance in sustaining leukemic cell proliferation and survival, the reduction of their levels could represent an effective strategy to reduce leukemic cells proliferation [59]. Moreover, Aronis et al. [62] demonstrated that a reduced ROS level could induce apoptosis by the involvement of death receptor in Jurkat cells.

In this context, our data show MG ability to exert scavenging and antioxidant activity leading to a significant reduction of ROS intracellular level which contributes to explain the pro-apoptotic effect induced by the activation of the extrinsic apoptotic pathway as indicated by FAS increased expression level.

The hypothesised pro-apoptotic mechanism of MG extract is summarized in the scheme shown in Fig. 10.

A fundamental feature of a good chemopreventive agent is the low toxicity towards healthy cells and the relative selectivity of action against tumor cells [63]. Therefore, the study was completed by evaluating MG cytotoxicity on PBL after $24 \mathrm{~h}$ of treatment.

MG demonstrated good selectivity as shown by the $\mathrm{IC}_{50}$, calculated for PBL by interpolation of the dose response curve, that resulted 2 and 1.7 times higher than those obtained on Jurkat and HL-60 cells respectively.

\section{Conclusions}

MG demonstrated good pro-apoptotic capacity in both Jurkat and HL-60 cell lines, with a predominant antiproliferative effect in HL-60 and to be partially selective towards leukemic cells. These findings allow to propose MG extracts as possible candidate as chemopreventive agents.

\footnotetext{
Abbreviations

7-AAD: 7-aminoactinomycin D; AAE/g: mg ascorbic acid equivalents; DCF: 2',7'-dichlorofluorescein; DCFH-DA: 2'-7'-dichlorodihydrofluorescin diacetate; DMSO: Dimethyl sulfoxide; DPPH: DPPH radical; EtOH: Ethanol; FBS: Fetal bovine serum; FCM: Flow cytometry; $\mathrm{Fe}^{2+}$ : Ferrous ions; FRAP: Ferric reducing antioxidant power; GAE/g: mg gallic acid equivalents; HL-60 cells: Acute promyelocytic leukemia; Jurkat cells: Acute T-cell lymphoblastic leukemia; L-GLU: L-Glutamine; MG: Meripilus giganteus; MGPS: MG a polysaccharide; MRM mode: Multiple reaction monitoring mode; NBT: Nitro blue tetrazolium; NEDA: N-(1-naphthyl) ethylenediamine dihydrochloride; $\mathrm{NO}$ : Nitric oxide; $\mathrm{O}_{2}$ : : Superoxide anion radical; $\mathrm{OH}$ : Hydroxyl radical; PBL: Human peripheral blood lymphocytes; PHA: Phitohemagglutinin; PI: Propidium iodide; PMS: 5-methylphenazin-5-ium methyl sulfate; PS: Penicillin-strptomicin; QE/g: mg quercetin equivalents; RPMI 1640 medium: roswell park memorial institute; SNP: Sodium nitroprusside; TBA: Tiobarbituric acid; TCA: Trichloroacetic acid; TF: Total flavonoid; TP: Total phenolic content; TPTZ: 2,4,6-tris(2-pyridyl)-s-triazine
}

\section{Funding}

The work on this paper is supported by project that has received funding from the European Union's Horizon 2020 Spreading Excellence and Widening Participation programme under grant agreement No 692276, and by the Ministry of Education, Science and Technological Development of the Republic of Serbia (Project No III 46001).

\section{Availability of data and materials}

Data presented in the manuscript are available upon motivated request.

\section{Authors' contributions}

ML, MM, AM, SH designed the study. ML, VC, AN, MK, MS, AM, MCB, performed the experiments. ML, MM, VC, AN, AM, MK, MS, MP, AC, PH, SH analyzed and discussed the data. ML, VC, MM, AN, MS, AM, SH wrote the manuscript. All authors read and approved the final version of the manuscript.

\section{Ethics approval and consent to participate}

Authorization to the use of human blood samples (Buffy coat), for research purposes, has been obtained from AUSL Bologna IT, S. Orsola-Malpighi Hospital - PROT GEN nº051937, and written informed consent was obtained by AUSL Bologna IT, S. Orsola-Malpighi Hospital from donors for the use of their blood for scientific research purposes.

\section{Consent for publication}

Not applicable.

\section{Competing interests}

The authors declare that they have no competing interests.

\section{Publisher's Note}

Springer Nature remains neutral with regard to jurisdictional claims in published maps and institutional affiliations.

\section{Author details}

${ }^{1}$ Department of Pharmacy and Biotechnology, University of Bologna, Via San Donato 15, 40127 Bologna, Italy. ${ }^{2}$ Institute of Food Technology, University of Novi Sad, Bul. Cara Lazara 1, Novi Sad 21000, Serbia. ${ }^{3}$ Faculty of Sciences, Department of Biology and Ecology, University of Novi Sad, Trg Dositeja Obradovića 2, Novi Sad 21000, Serbia. ${ }^{4}$ Department for Life Quality Studies, University of Bologna, Corso d'Augusto 237, 47921 Rimini, Italy. ${ }^{5}$ School of Pharmacy, University of Camerino, Via Madonna delle Carceri, 9 - 62032 Camerino, MC, Italy.

Received: 26 July 2018 Accepted: 30 October 2018

Published online: 12 November 2018

References

1. Tsai SY, Tsai HL, Mau JL. Antioxidant properties of Agaricus blazei, Agrocybe cylindracea, and Boletus edulis. LWT Food Sci Technol. 2007;40:1392-402.

2. Stamets P. Growing gourmet and medicinal mushrooms. New York: Ten Speed Press; 2000

3. Kalyoncu F, Oskay M, Saglam H, Erdogan TF, Tamer AU. Antimicrobial and antioxidant activities of mycelia of 10 wild mushroom species. J Med Food. 2010;13(2):415-9.

4. Lindequist $U$, Niedermeyer TH, Julich WD. The pharmacological potential of mushrooms. Evid Based Complement Alternat Med. 2005;2(3):285-99.

5. Karaman M, Jovin E, Malbasa R, Matavuly M, Popovic M. Medicinal and edible lignicolous fungi as natural sources of antioxidative and antibacterial agents. Phytother Res. 2010;24(10):1473-81.

6. Karaman M, Stahl M, Vulic J, Vesic M, Canadanovic-Brunet J. Wild-growing lignicolous mushroom species as sources of novel agents with antioxidative and antibacterial potentials. Int J Food Sci Nutr. 2014;65(3):311-9.

7. Maity P, Nandi AK, Manna DK, Pattanayak M, Sen IK, Bhanja SK, Samanta S, Panda BC, Paloi S, Acharya K, et al. Structural characterization and antioxidant activity of a glucan from Meripilus giganteus. Carbohydr Polym. 2017:157:1237-45

8. Acharya K, Rai M. Proximate composition, free radical scavenging and NOS activation properties of a wild edible mushroom. Int J Pharm Pharm Sci. 2013;5(1):67-72. 
9. Rai M, Sen S, Acharya K. Antimicrobial activity of four wild edible mushrooms from Darjeeling hills, West Bengal, India. Int J PharmTech Res. 2013;5(3):949-56

10. Tomasi S, Lohezic-Le Devehat F, Sauleau P, Bezivin C, Boustie J. Cytotoxic activity of methanol extracts from Basidiomycete mushrooms on murine cancer cell lines. Pharmazie. 2004;59(4):290-3.

11. Narbe $G$, Lindequist $U$, Teuscher E, Franke $P$, Vainiotalo $P$, Basner $R$. The chemistry of immunosuppressive acting fractions of Meripilus giganteus (PERS ex. FR.) KARST., the giant spore. Pharmazie. 1991;46(10):738-40.

12. Nam KS, Jo YS, Kim YH, Hyun JW, Kim HW. Cytotoxic activities of acetoxyscirpenediol and ergosterol peroxide from Paecilomyces tenuipes. Life Sci. 2001;69(2):229-37.

13. Kahlos K, Kangas L, Hiltunen R. Ergosterol peroxide, an active compound from Inonotus radiatus. Planta Med. 1989;55(4):389-90.

14. Singleton VL, Orthofer R, Lamuela-Raventós RM. Analysis of total phenols and other oxidation substrates and antioxidants by means of folin-ciocalteu reagent. Methods Enzymol. 1999;299:152-78.

15. Novaković AR, Karaman MA, Milovanović IL, Belović MM, Rašeta MJ, Radusin TI, Ilić NM. Edible mycorrhizal species Lactarius controversus Pers. 1800 as a source of antioxidant and cytotoxic agents. Hemijska Industrija. 2016;70(2): $113-22$.

16. Chang CC, Yang MH, Wen HM, Chern JC. Estimation of total flavonoid content in propolis by two complementary colorimetric methods. J Food Drug Anal. 2002;10(3):178-82.

17. Orcic D, Franciskovic M, Bekvalac K, Svircev E, Beara I, Lesjak M, MimicaDukic N. Quantitative determination of plant phenolics in Urtica dioica extracts by high-performance liquid chromatography coupled with tandem mass spectrometric detection. Food Chem. 2014;143:48-53.

18. Espin JC, Soler-Rivas C, Wichers HJ. Characterization of the total free radical scavenger capacity of vegetable oils and oil fractions using 2,2diphenyl-1-picrylhydrazyl radical. J Agric Food Chem. 2000;48(3):648-56.

19. Benzie IF, Strain JJ. Ferric reducing/antioxidant power assay: direct measure of total antioxidant activity of biological fluids and modified version for simultaneous measurement of total antioxidant power and ascorbic acid concentration. Methods Enzymol. 1999;299:15-27.

20. Green LC, Wagner DA, Glogowski J, Skipper PL, Wishnok JS, Tannenbaum SR. Analysis of nitrate, nitrite, and [15N]nitrate in biological fluids. Anal Biochem. 1982;126(1):131-8.

21. Cheeseman $\mathrm{KH}$, Beavis A, Esterbauer H. Hydroxyl-radical-induced ironcatalysed degradation of 2-deoxyribose. Quantitative determination of malondialdehyde. Biochem J. 1988;252(3):649-53.

22. Nishikimi M, Appaji N, Yagi K. The occurrence of superoxide anion in the reaction of reduced phenazine methosulfate and molecular oxygen. Biochem Biophys Res Commun. 1972;46(2):849-54

23. Fimognari C, Berti F, Cantelli-Forti G, Hrelia P. Effect of sulforaphane on micronucleus induction in cultured human lymphocytes by four different mutagens. Environ Mol Mutagen. 2005;46(4):260-7.

24. Lenzi M, Cocchi V, Malaguti M, Barbalace MC, Marchionni S, Hrelia S, Hrelia P. 6-(Methylsulfonyl) hexyl isothiocyanate as potential chemopreventive agent: molecular and cellular profile in leukaemia cell lines. Oncotarget. 2017;8(67):111697-714

25. Lenzi M, Malaguti M, Cocchi V, Hrelia S, Hrelia P. Castanea sativa Mill. bark extract exhibits chemopreventive properties triggering extrinsic apoptotic pathway in Jurkat cells. BMC Complement Altern Med. 2017;17(1):251.

26. Henry CM, Hollville E, Martin SJ. Measuring apoptosis by microscopy and flow cytometry. Methods. 2013;61(2):90-7.

27. Angeloni C, Malaguti M, Rizzo B, Barbalace MC, Fabbri D, Hrelia S. Neuroprotective effect of sulforaphane against methylglyoxal cytotoxicity. Chem Res Toxicol. 2015;28(6):1234-45.

28. Angeloni C, Hrelia S, Malaguti M. Neuroprotective effects of Glucosinolates. In: Mérillon JM, Ramawat KG, editors. Glucosinolates, reference series in phytochemistry. Switzerland: Springer International Publishing; 2016. p. 1-25.

29. Jurikova T, Mlcek J, Skrovankova S, Sumczynski D, Sochor J, Hlavacova I, Snopek L, Orsavova J. Fruits of black chokeberry Aronia melanocarpa in the prevention of chronic diseases. Molecules. 2017;22(6):944

30. Fimognari C, Ferruzzi L, Turrini E, Carulli G, Lenzi M, Hrelia P, Cantelli-Forti G. Metabolic and toxicological considerations of botanicals in anticancer therapy. Expert Opin Drug Metab Toxicol. 2012;8(7):819-32.

31. Zhang H, Tsao R. Dietary polyphenols, oxidative stress and antioxidant and anti-inflammatory effects. Curr Opin Food Sci. 2016;8:33-42.
32. Zhang C, Shu L, Kim H, Khor TO, Wu R, Li W, Kong AN. Phenethyl isothiocyanate (PEITC) suppresses prostate cancer cell invasion epigenetically through regulating microRNA-194. Mol Nutr Food Res. 2016; 60(6):1427-36.

33. Angeloni C, Malaguti M, Barbalace MC, Hrelia S. Bioactivity of olive oil phenols in neuroprotection. Int J Mol Sci. 2017;18(11):E2230.

34. Malaguti M, Angeloni C, Hrelia S. Nutraceutical bioactive compounds promote healthspan counteracting cardiovascular diseases. J Am Coll Nutr. 2015;34(Suppl 1):22-7.

35. Chiarini A, Micucci $M$, Malaguti M, Budriesi R, loan $P$, Lenzi $M$, Fimognari C, Gallina Toschi T, Comandini P, Hrelia S. Sweet chestnut (Castanea sativa Mill.) bark extract: cardiovascular activity and myocyte protection against oxidative damage. Oxidative Med Cell Longev. 2013; 2013:471790.

36. Micucci M, Malaguti M, Toschi TG, Di Lecce G, Aldini R, Angeletti A, Chiarini A, Budriesi R, Hrelia S. Cardiac and vascular synergic protective effect of Olea europea L. Leaves and Hibiscus sabdariffa L. Flower Extracts. Oxidative Med Cell Longev. 2015;2015:318125.

37. Klaus A, Kozarski M, Niksic M, Jakovljevic D, Todorovic N, Stefanoska I, Van Griensven $\sqcup$. The edible mushroom Laetiporus sulphureus as potential source of natural antioxidants. Int J Food Sci Nutr. 2013;64(5):599-610.

38. Zhang S, Liu X, Yan L, Zhang Q, Zhu J, Huang N, Wang Z. Chemical compositions and antioxidant activities of polysaccharides from the sporophores and cultured products of Armillaria mellea. Molecules. 2015; 20(4):5680-97.

39. Trumbeckaite $S$, Benetis $R$, Bumblauskiene $L$, Burdulis $D$, Janulis $V, T$, Viskelis $P$, Jakstas V. Achillea millefolium L.s.l. herb extract: antioxidant activity and effect on the rat heart mitochondrial functions. Food Chem. 2011:127:1540-8.

40. Keles A, Koca I, Gençcelep H. Antioxidant properties of wild edible mushrooms. J Food Process Technol. 2011;2(6):130.

41. Yildiz O, Can Z, Laghari AQ, Ahin SH, Malkoç M. Wild edible mushrooms as a natural source of Phenolics and antioxidants. J Food Biochem. 2015;39: $148-54$

42. Alvarez-Parrilla E, de la Rosa LA, Martínez NR, Aguilar-González GA. Total phenols and antioxidant activity of commercial and wild mushrooms from Chihuahua, Mexico. CYTA J Food. 2007:5(5):329-34.

43. Ribeiro B, Valentao P, Baptista P, Seabra RM, Andrade PB. Phenolic compounds, organic acids profiles and antioxidative properties of beefsteak fungus (Fistulina hepatica). Food Chem Toxicol. 2007;45(10):1805-13.

44. Vaz JA, Barros L, Martins A, Morais JS, Vasconcelos MH, Ferreira IC. Phenolic profile of seventeen Portuguese wild mushrooms. LWT Food Sci Technol. 2011;44(1):343-6.

45. Barros L, Cruz T, Baptista P, Estevinho LM, Ferreira IC. Wild and commercial mushrooms as source of nutrients and nutraceuticals. Food Chem Toxicol. 2008:46(8):2742-7

46. Heleno SA, Martins A, Queiroz MJ, Ferreira IC. Bioactivity of phenolic acids: metabolites versus parent compounds: a review. Food Chem. 2015;173:501-13.

47. Ferreira ICFR, Baptista P, Vilas-Boas M, Barros L. Free-radical scavenging capacity and reducing power of wild edible mushrooms from Northeast Portugal: individual cap and stipe activity. Food Chem. 2007;100(4):1511-6.

48. Puttaraju NG, Venkateshaiah SU, Dharmesh SM, Urs SM, Somasundaram R. Antioxidant activity of indigenous edible mushrooms. J Agric Food Chem. 2006;54(26):9764-72.

49. Lenzi M, Fimognari C, Hrelia P. Sulforaphane as a promising molecule for fighting cancer. Cancer Treat Res. 2014;159:207-23.

50. Arora S, Tandon S. Mushroom extracts induce human colon cancer cell (COLO-205) death by triggering the mitochondrial apoptosis pathway and go/G1-phase cell cycle arrest. Arch Iran Med. 2015;18(5):284-95.

51. Leon F, Quintana J, Rivera A, Estevez F, Bermejo J. Lanostanoid triterpenes from Laetiporus sulphureus and apoptosis induction on HL-60 human myeloid leukemia cells. J Nat Prod. 2004;67(12):2008-11.

52. Abubakar MB, Abdullah WZ, Sulaiman SA, Suen AB. A review of molecular mechanisms of the anti-leukemic effects of phenolic compounds in honey. Int J Mol Sci. 2012;13(11):15054-73.

53. Fimognari C, Lenzi M, Cantelli-Forti G, Hrelia P. Induction of differentiation in human promyelocytic cells by the isothiocyanate sulforaphane. In Vivo. 2008;22(3):317-20.

54. Harrington HA, Ho KL, Ghosh S, Tung KC. Construction and analysis of a modular model of caspase activation in apoptosis. Theor Biol Med Model. 2008;5:26. 
55. Li L, Zhang R, Chen Z, Xue S, Wang X, Ruan C. Over-expressed Fas improves the apoptosis of malignant T-cells in vitro and vivo. Mol Biol Rep. 2011;38(8):5371-7.

56. Autret $\mathrm{A}$, Martin $\mathrm{SJ}$. Emerging role for members of the $\mathrm{BCl}-2$ family in mitochondrial morphogenesis. Mol Cell. 2009;36(3):355-63.

57. Wang Z, Tang X, Zhang Y, Qi R, Li Z, Zhang K, Liu Z, Yang X. Lobaplatin induces apoptosis and arrests cell cycle progression in human cholangiocarcinoma cell line RBE. Biomed Pharmacother. 2012;66(3):161-6.

58. Szatrowski TP, Nathan CF. Production of large amounts of hydrogen peroxide by human tumor cells. Cancer Res. 1991;51(3):794-8.

59. Prieto-Bermejo R, Romo-Gonzalez M, Perez-Fernandez A, ljurko C, Hernandez-Hernandez A. Reactive oxygen species in haematopoiesis: leukaemic cells take a walk on the wild side. J Exp Clin Cancer Res. 2018; 37(1):125

60. Sallmyr A, Fan J, Rassool FV. Genomic instability in myeloid malignancies: increased reactive oxygen species (ROS), DNA double strand breaks (DSBs) and error-prone repair. Cancer Lett. 2008;270(1):1-9.

61. Hole PS, Darley RL, Tonks A. Do reactive oxygen species play a role in myeloid leukemias? Blood. 2011;117(22):5816-26

62. Aronis A, Melendez JA, Golan O, Shilo S, Dicter N, Tirosh O. Potentiation of Fas-mediated apoptosis by attenuated production of mitochondria-derived reactive oxygen species. Cell Death Differ. 2003;10(3):335-44.

63. Fimognari C, Lenzi M, Hrelia P. Apoptosis induction by sulfur-containing compounds in malignant and nonmalignant human cells. Environ Mol Mutagen. 2009;50(3):171-89.

Ready to submit your research? Choose BMC and benefit from:

- fast, convenient online submission

- thorough peer review by experienced researchers in your field

- rapid publication on acceptance

- support for research data, including large and complex data types

- gold Open Access which fosters wider collaboration and increased citations

- maximum visibility for your research: over $100 \mathrm{M}$ website views per year

At $\mathrm{BMC}$, research is always in progress.

Learn more biomedcentral.com/submissions 